\title{
A PARTURITION AND NURSERY AREA FOR CARCHARHINUS LIMBATUS (ELASMOBRANCHII, CARCHARHINIDAE) OFF THE COAST OF PARANÁ, BRAZIL
}

\author{
Hugo Bornatowski \\ Programa de Pós-Graduação em Zoologia, Departamento de Zoologia, Universidade Federal do Paraná \\ (Caixa Postal 19020, 81531-980 Curitiba, PR, Brasil) \\ anequim.bio@gmail.com
}

Many carcharhinids are negatively affected by fisheries and habitat degradation worldwide. Larger species generally have late maturation, relatively low fecundities and are particularly vulnerable to overfishing as targeted species or bycatch. They are also threatened by the degradation of inshore nursery areas resulting from human development and pollution. Several species of requiem sharks are now protected in North-American waters as a legal reaction to the dramatic declines in catches, and several species have been placed on the IUCN Red List of Threatened Species by the IUCN (International Union for Conservation of Nature and Natural Resources) Shark Specialist Group (COMPAGNO; NIEM, 1998).

Except for the possibly aplacental viviparous or semiplacental tiger shark (Galeocerdo cuvier), all carcharhinids are placental viviparous species with a yolk-sac placenta, and have litters of 1 to 135 pups (COMPAGNO; NIEM, 1998).

Carcharhinus limbatus has widespread distribution, occurring in all tropical and subtropical coastal waters, extending northward to New England (rare) and south to southern Brazil. It is considered the most common shark around the Bahamas Islands and off southern Florida and is also very common around the Antilles and off the northwest coast of South America (COMPAGNO, 1984). In Brazil, it has been recorded along the entire continental shelf, including the oceanic islands but rarely in pelagic regions
(GADIG, 2001). The present work presents new information on the reproductive cycle of $C$. limbatus in southern Brazil.

Between June 2006 and July 2007, observations of fish landings were conducted on Ipanema beach, located on the Pontal do Paraná, Paraná State $\left(25^{\circ} 39^{\prime} \mathrm{S}, 48^{\circ} 26^{\prime} \mathrm{W}\right)$. Specimens were caught using anchored gillnets, mesh-sizes of 16 and $45 \mathrm{~cm}$ (stretched mesh), at a maximum distance of 12 miles from the coast. The uteri of three pregnant females and four newborn $C$. limbatus were collected. Only pregnant females were caught in the study area.

All embryos and newborns were analyzed: the general characteristics of their developmental stage were observed and morphometric data such on total length (TL) $(\mathrm{cm})$ and tooth length $(\mathrm{cm})$ were recorded. The data were compared with those of other studies to determine the birth period of the C. limbatus embryos. One embryo was deposited in the fish collection of the Museu de História Natural Capão da Imbuia (MHNCI 11718).

Three pregnant females $(200-215 \mathrm{~cm} \mathrm{TL})$ were caught carrying a total of 20 embryos, measuring between 51.5 and $57.6 \mathrm{~cm}$ (TL) (Table 1), resulting in a mean of 6.6 embryos per female. All the embryos were at an advanced stage of development, characterized by well-defined ampullae of Lorenzini and body coloration as well as developed dentition and fully-formed internal organs.

Table 1. Uterus data of pregnant females of C. limbatus caught on Ipanema beach, Pontal do Paraná, southern Brazil.

\begin{tabular}{cccccc}
\hline \hline $\begin{array}{c}\text { Female } \\
\text { number }\end{array}$ & Month of catch & Total embryos & $\begin{array}{c}\text { Length of the tooth } \\
\text { of embryos } \\
\text { min./max. }(\mathrm{cm})\end{array}$ & $\begin{array}{c}\text { Number of embryos } \\
\text { analyzed } \\
\text { male/female }\end{array}$ & $\begin{array}{c}\text { Total length } \\
\text { embryos min./max. } \\
(\mathrm{cm})\end{array}$ \\
\hline 01 & October 2006 & 06 & $0.1 / 0.1$ & $03 / 03$ & $51.5 / 53.7$ \\
02 & November 2006 & 08 & $0.1 / 0.2$ & $03 / 05$ & $55.6 / 57.6$ \\
03 & November 2006 & 06 & $0.1 / 0.1$ & $03 / 03$ & $55.2 / 56.1$ \\
\hline
\end{tabular}


Embryos of $C$. limbatus are born at between 55 and $65 \mathrm{~cm}$ length (TL) (CASTRO, 1993; DUDLEY; CLIFF, 1993; CASTRO, 1996; CASTILLO-GÉNIZ, 1998). YOKOTA; LESSA, 2006 captured 32 newborns of $C$. limbatus in northern Brazil, with total lengths of between 59.2 and $68.2 \mathrm{~cm}$. According to the information available on biological and reproductive parameters of $C$. limbatus, all the embryos recorded in the present study were close to the length-at-birth previously reported for the species. The conditions of dentition and internal organs are important descriptors of the process of embryonic development. Costa et al. (2002) studied embryos and newborns of Isurus oxyrinchus in Southeastern Brazil and reported that embryos with well developed dentition and internal organs present advanced stages of development.

The newborns had recorded total lengths ranging from 59.4 to $68.0 \mathrm{~cm}$ (Table 2). C. limbatus reaches a maximum reported length of $250 \mathrm{~cm}$ (TL), with males reaching maturity at approximately $140 \mathrm{~cm}$ (TL) and females maturing at approximately $150 \mathrm{~cm}$ (TL) (CASTRO, 1996). Local fisherman report a common occurrence of newborn C. limbatus in spring and summer.

Table 2. Newborn data on C. limbatus caught off Ipanema beach, Pontal do Paraná, southern Brazil.

\begin{tabular}{cccc}
\hline \hline $\begin{array}{c}\text { Newborn } \\
\text { number }\end{array}$ & Month of catch & $\begin{array}{c}\text { Total } \\
\text { length } \\
(\mathrm{cm})\end{array}$ & $\begin{array}{c}\text { Tooth } \\
\text { length }(\mathrm{cm})\end{array}$ \\
\hline 01 & December 2006 & 68.0 & 0.4 \\
02 & December 2006 & 65.0 & 0.4 \\
03 & January 2007 & 60.6 & 0.2 \\
04 & February 2007 & 59.4 & 0.2 \\
\hline
\end{tabular}

Although the newborn pups and pregnant females were captured using the same gear (anchored gillnets), the former were caught in nets of $16 \mathrm{~cm}$ mesh-size and the latter in nets of $45 \mathrm{~cm}$ mesh-size. Thus, the specimens captured can be successfully selected by size in accordance with the mesh-size used.

Coastal regions are generally used for parturition and as nursery areas by many elasmobranch species. Yokota and Lessa (2006) classified the northern coast of Brazil as a nursery area for Carcharhinus acronotus, $C$. limbatus, $C$. falciformis and Rhizoprionodon porosus while Carcharias taurus depends on nursery areas in the state of Rio Grande do Sul (NISA-CASTRO-NETO,
2001). The capture of newborn and juvenile specimens in nursery areas is one of the greatest threats to shark populations (BONFIL, 1997).

The capture of pregnant females in the spring with embryos at advanced stages of development and of newborn specimens with lengths of between 59.4 and $68.0 \mathrm{~cm}$ (TL) in summer, suggests a well-defined reproductive period for the species off the coast of Paraná. The period of parturition for pregnant females is the spring and early summer, when embryos reach total lengths of between 55 and $65 \mathrm{~cm}$. Newborn sharks probably remain in the coastal nursery for approximately three months (CASTRO, 1996). The complete reproductive cycle of C. limbatus, however, cannot be established on the basis of the present data.

The central portion of the coast of Paraná may also be considered an area of parturition and nursery for $C$. limbatus.

\section{ACKNOWLEDGEMENTS}

The authors wish to thank Walter Nisa Castro-Neto, Amanda Andrade and Akemi Shibuya for reviewing the manuscript and for their helpful comments; as also the fishermen of Ipanema beach for their permission for them to analyze the specimens.

\section{REFERENCES}

BONFIL, R. Status of sharks' resources in the southern Gulf of Mexico and Caribbean: implications for management. Fish. Res. v. 29, p. 101-117, 1997.

CASTILLO-GÉNIZ, J. L.; MÁRQUES-FARIAS, J. F.; CRUZ, M. C. R.; CORTÉS, E.; PRADO, A. C. The Mexican artisanal shark fishery in the Gulf of Mexico: towards a regulated fishery. Mar. Freshwat. Res., v. 49, p. 611-620, 1998

CASTRO, J. I. The shark nursery of Bulls Bay, South Carolina, with a review of the shark nurseries of the southeastern coast of the United States. Environ. Biol. Fishes, v. 38, p. 37-48. 1993.

CASTRO, J. I. Biology of the blacktip shark Carcharhinus limbatus, off the southeastern United States. Bull. mar. Sci., v. 59, n. 3, p. $508-522,1996$.

COMPAGNO, L. J. V. FAO Species Catalogue. In: Sharks of the world. An annotated and illustrated catalogue of shark species known to date. Part 1-2. Rome: FAO, 1984. FAO Fish Synopsis, v. 4: 1-665, 1984.

COMPAGNO, L. J. V.; NIEM, V. H. Carcharhinidae. In: CARPENTER, K. E.; NIEM, V. H. (Ed.). FAO species identification guide for fishery purposes. The living marine resources of the Western Central Pacific. V.2. Cephalopods, crustaceans, holothurians and sharks. Rome: FAO, 1998. p. 1312-1324.

COSTA, F. E. S.; BRAGA, F. M. S.; ARFELLI, C. A.; AMORIM, A. F. Aspects of the reproductive biology of the shortfin mako, Isurus oxyrinchus (Elasmobranchii Lamnidae), in the southeastern region of Brazil. Braz. J. Biol., v. 62, n. 2, p. 239-248. 2002. 
DUDLEY, S. F. J.; CLIFF, G. Sharks caught in the protective gill nets off Natal, South Africa. 7. The blacktip shark Carcharhinus limbatus (Valenciennes). S. Afr. J. mar. Sci., v.13, p. 237-254, 1993.

YOKOTA, L.; LESSA, R. P. A nursery area for sharks and rays in Northeastern Brazil. Environ. Biol. Fishes, v. 75, p. 349-360, 2006.

Source of Unpublished Material

GADIG, O. B. F. Tubarões da costa brasileira. Tese (Doutorado). Universidade Estadual Paulista, Instituto de Biociências de Rio Claro, São Paulo, 2001.

NISA-CASTRO-NETO, W. Análise da Pesca de Carcharias taurus Rafinesque, $1810 \quad$ (Chondrichthyes, Odontaspididae) e seu Declínio nas Regiões Sul e Sudeste do Brasil. Dissertação (Mestrado), Faculdade de Biociências, Pontifícia Universidade Católica do Rio Grande do Sul, Porto Alegre, 2001.

(Manuscript received 08 April 2008; revised 01 July 2008; accepted 04 July 2008) 